\title{
MOSSES OF THE MUS-KHAYA MOUNTAIN (YAKUTIA, ASIATIC RUSSIA)
}

\author{
МХИ ГОРЫ МУС-ХАЯ (ЯКУТИЯ, АЗИАТСКАЯ РОССИЯ) \\ E.A. IGNATOVA ${ }^{1}$, E.I. IVANOVA ${ }^{2}$, O.V. IVANOV ${ }^{3}$, M.S. IGNATOV ${ }^{4}$ \\ Е.А. ИГНАТОВА ${ }^{1}$, Е.И. ИВАНОВА ${ }^{2}$, О.В. ИВАНОВ ${ }^{3}$, М.С. ИГНАТОВ ${ }^{4}$
}

Резюме

Moss flora of the area around the second highest peak of Yakutia, the MusKhaya Mt., is studied. This area is close to the coldest place of the Northern Hemisphere. Severe condition and high content of heavy metals result is a rather poor diversity of 180 species; their list is annotated by altitudinal range, frequency, locality and habitat information. Map of Gollania turgens is provided; Mielichhoferia mielichhoferiana, M. elongata and Andreaea papillosa are discussed and illustrated.

Резюме

Исследована флора мхов в районе горы Мус-Хая, второй высочайшей вершины Якутии. Этот район находится в непосредственной близости к полюсу холода Северного полушария. Суровые условия и высокое содержание тяжелых металлов обуславливают относительную бедность флоры мхов, включающей 180 видов. Аннотированный список содержит информацию о высотном диапазоне, частоте встречеаемости видов, точкам сбора и местообитаниям. Приводится карта распространения Gollania turgens, обсуждение и иллюстрации Mielichhoferia mielichhoferiana, M. elongata и Andreaea papillosa.

KEYWORDS: mosses, flora, metallophytes, Yakutia, Suntar-Khayata Range

\section{INTRODUCTION}

The moss flora of Republic of Sakha (Yakutia) has got recently a comprehensive overview in the checklist of Ivanova et al. (2005), although its huge territory, the largest administrative unit of the Russian Federation, 3,104,000 square km, is still too underexplored. The territory of the eastern part of Suntar-Khayata Range, near Mus-Khaya Peak, the second highest mountain in Yakutia, $2959 \mathrm{~m}$, has never been visited by botanists earlier.

The name Mus-Khaya means "Ice mountain" in the Yakutian language. It is the highest point of Suntar-Khayata Range and has glaciers of ca.
245 sq. $\mathrm{km}$, being the largest glaciated area in the North-East Siberia. The Kongor and Suntar Rivers originating from this mountain area belong to the Indigirka River Basin, Yudoma River flows to the Maya, then to the Aldan, and then to the Lena River, while the D'yakul is a tributary of the Okhota which flows south to the Okhotsk Sea.

This area is close to the coldest place of the Northern Hemisphere, Oimyakon, where $-71.2^{\circ} \mathrm{C}$ has been recorded. The permafrost exceeds 700 $\mathrm{m}$ thick. The nearest meteostations provide the parameters shown in Table 1.

Bedrocks are mostly non-carbonate and include schists, aleurolites, sandstones, with grani-

1 - Moscow State University, Biological Faculty, Geobotany Dept., Moscow 119991 Russia - Россия 119991, Москва, Московский университет, Биологический факультет, каф. геоботаники; e-mail: arctoa@list.ru

2 - Institute for Biological Problems of Cryolithozone of Siberian Division of Russian Academy of Sciences, 41 Lenin ave., Yakutsk, 677000, Russia - Россия 677000 Якутск, пр. Ленина, д. 41, Институт биологических проблем криолитозоны CO PAH; e-mail: mosses07@rambler.ru

3 - P.N. Lebedev' Institue of Physics of Russ. Acad. Sci., Leninsky 53, Moscow 119991 Russia - Россия 119991, Москва, Ленинский проспект, 53, ФИАН, e-mail: ivanov@td.lpi.ru

4 - Main Botanical Garden, Russian Academy of Sciences, Botanicheskaya 4, Moscow 127276 Russia - Россия 127276 Москва, Ботаническая 4, ГБС РАН, e-mail: misha_ignatov@list.ru 


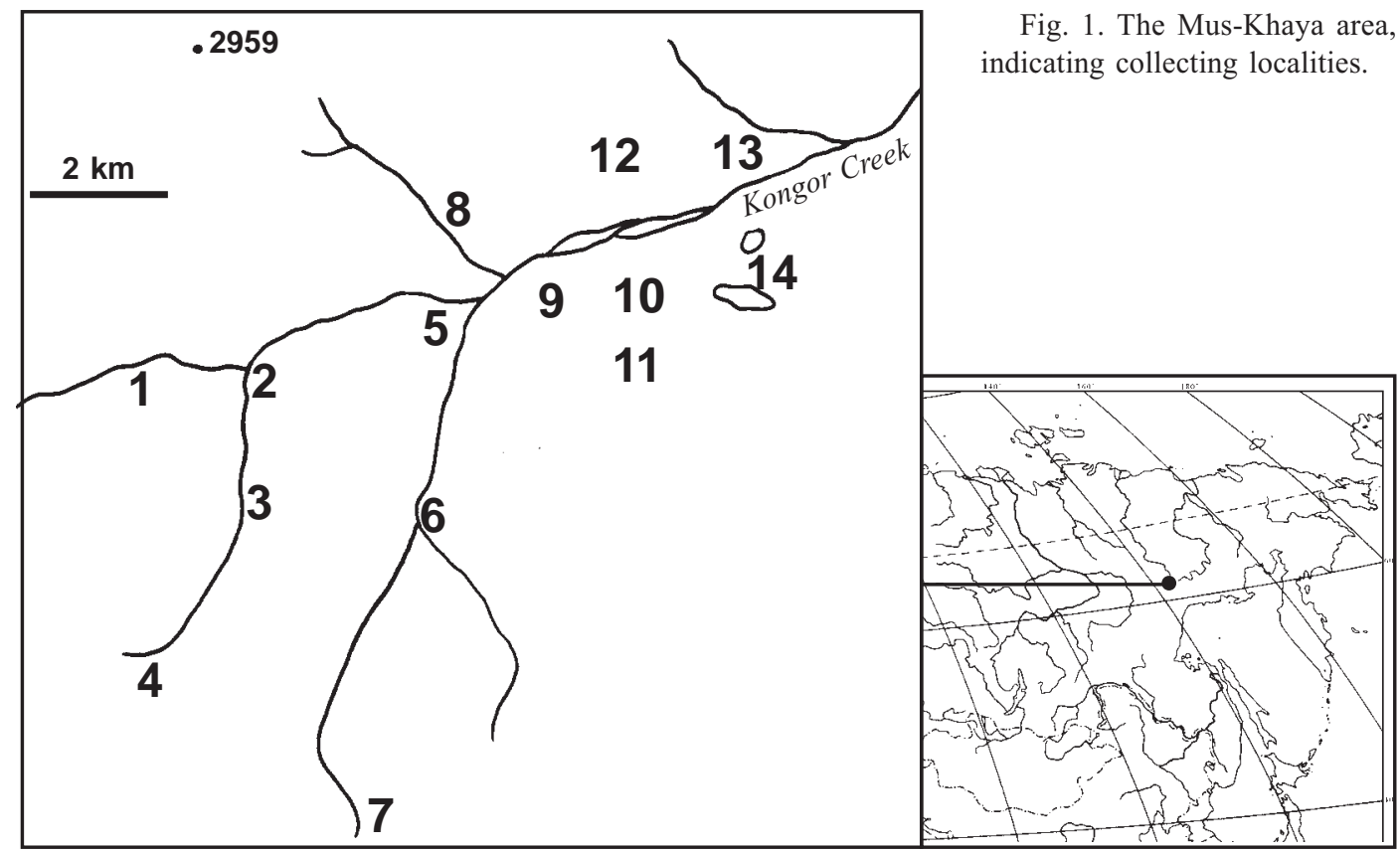

toid intrusions and acid effusives. Rocks in the area are especially rich in $\mathrm{MnS}$, and other heavy metals ( $\mathrm{Pb}, \mathrm{Sn}, \mathrm{As}, \mathrm{Zn}, \mathrm{Ag}$, etc., usually as sulphides) present in high concentrations, so many brooks have very acid water and sulphur deposits along them. Siderite (iron carbonate) forms red outcrops, but is likely always enriched by other heavy metals, judging on the constant occurrence of Coscinodon and Mielichhoferia.

The territory belonged to the volcanic belt in the late Mesozoic time, and uplift of the area is still continuing, resulting in sharp ridges. Slopes are mostly very steep and covered by screes, and at places where rock pieces are relatively small, no mosses can survive, due to dry climate and temporary very hot days in summer, as the daytime exceeds 20 hours at this latitude. Snow-fields are extensive on $\mathrm{N}$-facing slopes, but due to hot summer they usually totally melt by the end of August.

July 12-17, 2011 we collected mosses in the area near Mus-Khaya Peak $\left(62^{\circ} 31^{\prime}-36^{\prime} \mathrm{N}\right.$, $\left.140^{\circ} 56^{\prime}-141^{\circ} 07^{\prime} \mathrm{E}\right)$ as it is shown in the map (Fig. 1), which likely allowed a revealing of species diversity as complete as it is commonly done by similar exploration studies. Elevations of 1450 to $1950 \mathrm{~m}$ were studied, as the slopes above are very steep and formed by unstable rock-fields which are very dry and lack any mosses, where we were able to check them (Figs. 2A-B, E).
The main types of habitat in the area include (cf. also Figs. 2-3):

1. Larix cajanderi forest (Fig. $2 \mathrm{G}, \mathrm{H}$ ) with Vaccinium vitis-idea, $V$. uliginosum, Ledum palustre subsp. decumbens, Betula exilis (B. nana p.p.) and $B$. divaricata. Mosses are less widespread than lichens, and the most common are Rhytidium rugosum, Hylocomium splendens var. alaskanum, Aulacomnium turgidum, Dicranum elongatum, and more rarely Pleurozium schreberi, Sphagnum lenense, Sanionia uncinata. Forest vegetation reaches $1600-1650 \mathrm{~m}$ on S-faced slopes, although scattered trees were seen up to at least 1750 $\mathrm{m}$ elev. However below the timber-line the tundra communities are common as well, alternating with forest in more wind-protected places.

2. Mires and bogs can be classified here in three main types:

2a: Sphagnum communities in wet tundra, at lake shores and in forests, usually of quite limited size, performing transition to forest communities. Rather dense Betula nana shrubs often have mosses more abundant than lichens and then composed of Sphagnum lenense, Tomentypnum nitens, Aulacomnium turgidum, Hylocomium, Pleurozium, Tomentypnum, Dicranum elongatum, etc.

2b: Springy fens and hummocks (e.g. Fig. 2H) are composed of Cinclidium spp., Meesia uligi- 

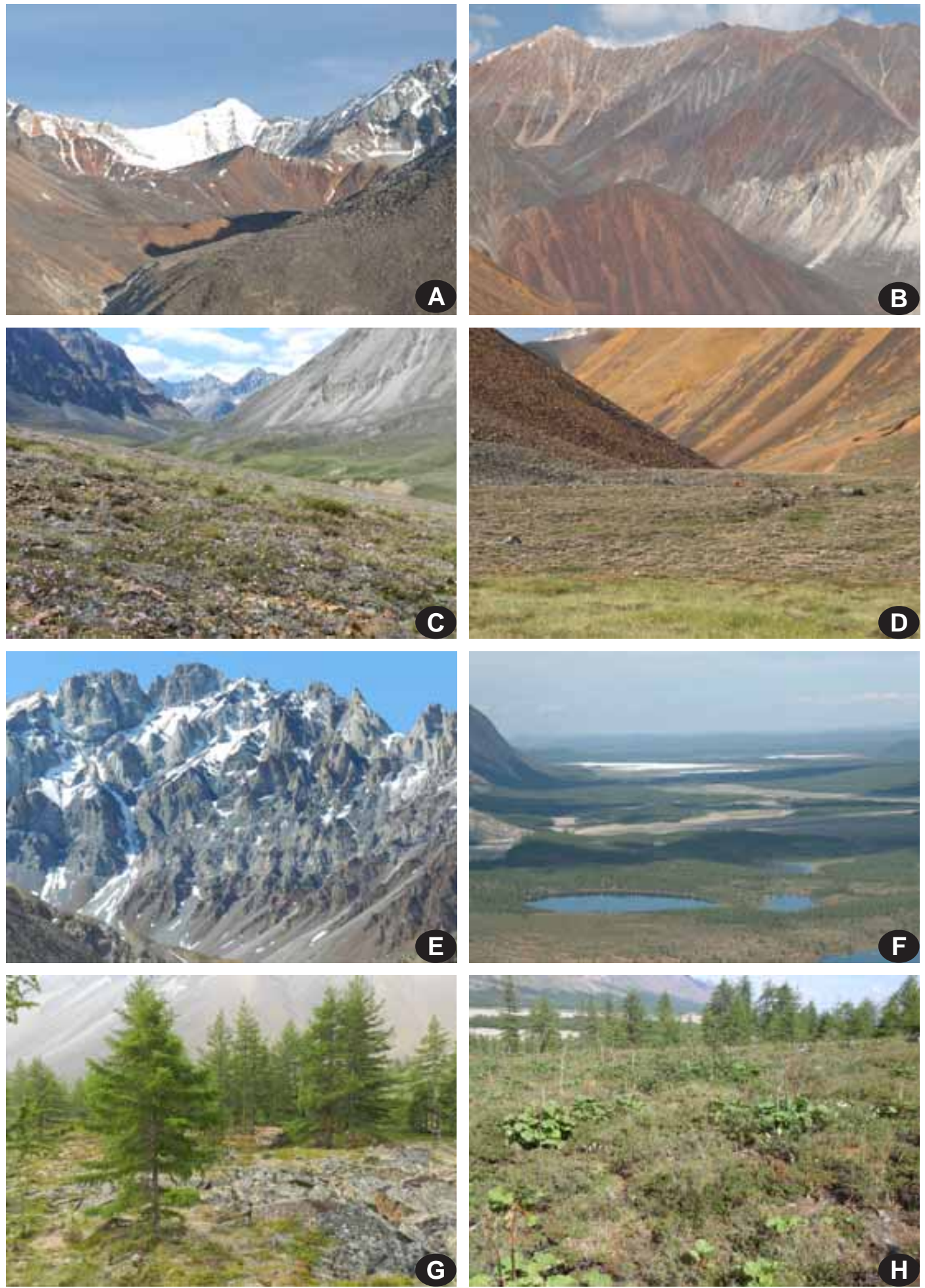

Fig. 2. A - Mus-Khaya Peak (2959 m); B-E - mountain slopes, showing alternation of red, grey and white rocks; F - Kongor Creek valley, showing scattered Larix forest and permanent valley ice-field; G - rock-field among open Larix forest; $\mathrm{H}$ - mire with Rheum, a habitat of Cinclidium, Loeskypnum, Meesia, etc. 

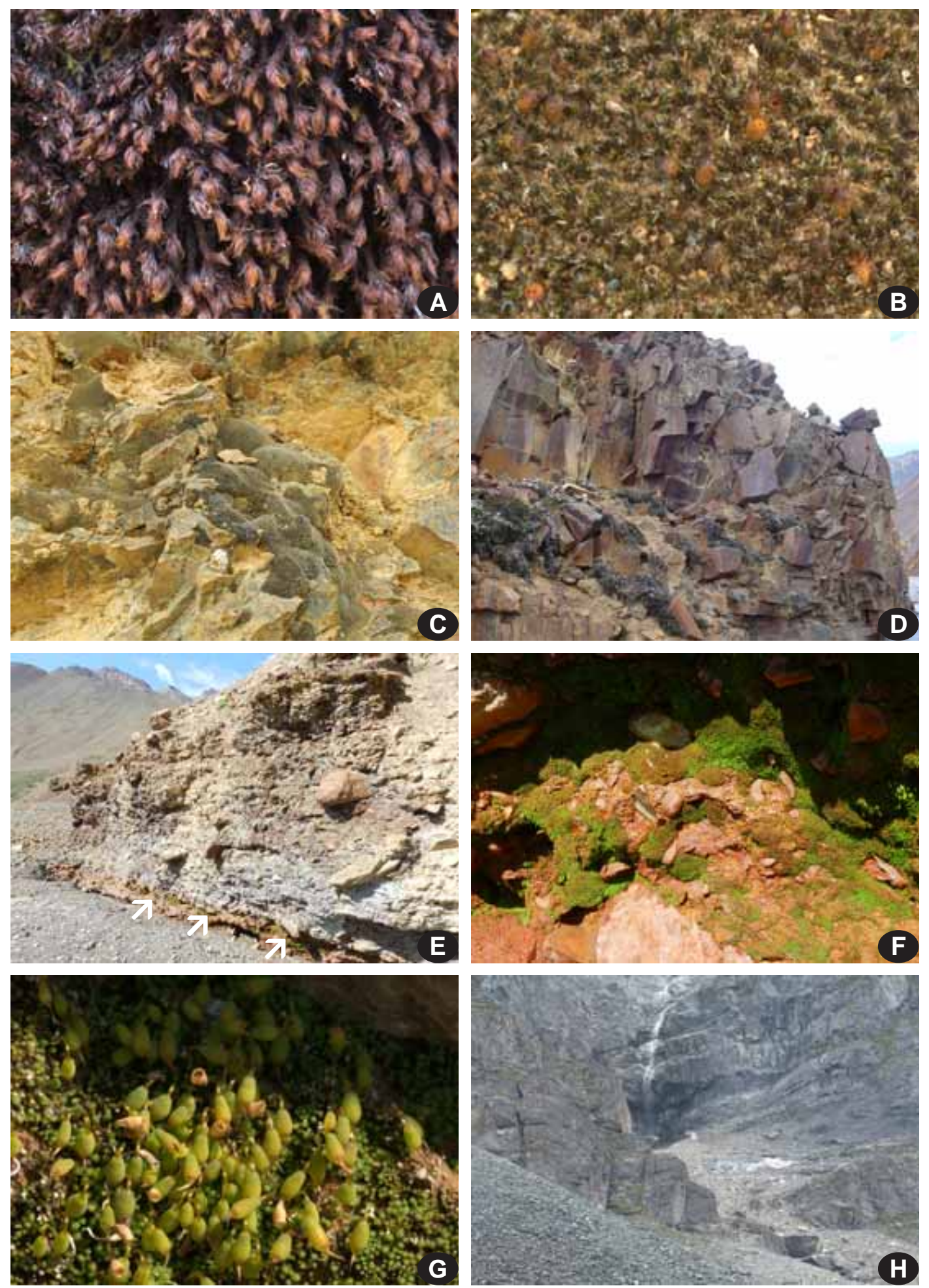

Fig. 3. A - Andreaea papillosa; B-D - Concinodon hartzii and its habitats; E-G - Mielichhoferia mielichhorefiana and its habitats (arrowed in E); $\mathrm{H}$ - cliffs near waterfall, the habitat of Gollania turgens. 
Table 1. Meteorological data from the nearest stations (according to Monthly meteorological data, 1985-1989).

\begin{tabular}{|c|c|c|c|c|}
\hline $\begin{array}{l}\text { Meteostation and distance } \\
\text { from Mus-Khaya }\end{array}$ & $\begin{array}{l}\text { mean } \\
\text { annual } \mathrm{t}^{\circ} \mathrm{C}\end{array}$ & $\begin{array}{l}\text { mean } \\
\text { January } \mathrm{t}^{\circ} \mathrm{C}\end{array}$ & $\begin{array}{l}\text { mean } \\
\text { July } \mathrm{t}^{\circ} \mathrm{C}\end{array}$ & $\begin{array}{l}\text { annual } \\
\text { precipitation, } \mathrm{mm}\end{array}$ \\
\hline $\begin{array}{l}\text { Vostochnaya ( } 98 \mathrm{~km} \text { to } \mathrm{NW} \text {, } \\
\text { ca. } 1000 \mathrm{~m} \text { alt.) }\end{array}$ & -13 & -36 & +12 & 256 \\
\hline $\begin{array}{l}\text { Agayakan ( } 88 \mathrm{~km} \text { to } \mathrm{N}, \\
\text { ca. } 200 \mathrm{~m} \text { alt.) }\end{array}$ & -15 & -47 & +15 & 215 \\
\hline $\begin{array}{l}\text { Oimyakon (135 km to NE, } \\
\text { ca. } 150 \mathrm{~m} \text { alt.) }\end{array}$ & -16 & -48 & +14 & 211 \\
\hline
\end{tabular}

nosa, Loeskypnum badium, Scorpidium revolvens, Tomentypnum nitens, Orthothecium chryseum, Rhizomnium andrewsianum.

2c: Warnstorfia mires in wet Carex stans and Eriophorum polystachyon communities at low banks of small lakes are often flooded by melted permafrost. Aulacomnium turgidum and Sphagnum spp. occur here at places.

3. Brook beds have rocks covered by Bryum cryophilum, B. cyclophyllum, Hygrohypnella polaris and Orthothecium chryseum, Schisitium platyphyllum, closer to snow-fields Andreaea papillosa is also common, and at places $A$. rupestris, and in one place also A. obovata occurs. Shallow banks that are often temporarily flooded (in daytime) have often an extensive cover of Polytrichum jensenii, sometimes intermixed with Pogonatum dentatum and Polytrichum hyperboreum. Moist temporarily flooded depressions among big rocks in rock-fields are characterized by Aulacomnium palustre var. imbricatum and Nichotrichum canescens (in flooded places lacking hyaline hair points). Surprisingly Oncophorus virens and Philonotis tomentella are not common along brooks.

4. Rather dry tundra is dominated by lichens, Betula exilis, Cassiope tetragona, Dryas punctata, D. octopetala subsp. subincisa, Ledum palusre, Vaccinium uliginosum, etc. Some areas have abundant Claytona sp. populations (Fig. 2C). Mosses of these communities are not abundant and include Ceratodon purpureus, Rhytidium rugosum, Aulacomnium turgidum, Dicranum elongatum, Tortella fragilis, Racomitrium lanuginosum, Encalypta rhaptocarpa, Syntrichia ruralis, Abietinella abietina, Conostomum tetragonum, Distichium capllaceum, etc.

5. 'Red rocks' (rich in iron and heavy metal, Figs. 3D-E) are characterized by the abundant
Coscinodon hartzii (Figs. 3B, C), as well as the rather constant presence of Mielichhoferia mielichhoferiana. When outcrops are dry, the former species is the only moss on this substrate (Fig.3E$\mathrm{G})$ or at least the only more or less abundant one. In more shaded and wet situations there are additions of Arctoa fulvella, Pohlia crudoides, Oligotrichum falcatum, Andreaea papillosa, Polytrichum hyperboreum. Red rocks rather rapidly break into small pieces forming readily eroded slopes, so rock-fields formed by red rocks do not provide any room for mosses.

6. Grey rocks (separate boulders, small outcrops and cliff faces) are rather poor in mosses, probably due to very severe and dry climate. Common are only Grimmia longirostris, Schistidium pulchrum, Rhytidium rugosum and Andreaea rupestris; at places G. reflexidens and Dicranoweisia crispula occur. Interestingly, the only collection of Seligeria campylopoda was made on a rather exposed rock face, unlike typical growth of many species of the genus in caves, on overhangs and otherwise sheltered rock faces.

7. Grey rocks (rock-fields). Niches among big rocks have more hepatics than mosses, and among the latter common are Cynodontium spp., Sanionia uncinata, Syntrichia, Cnestrum, Ditrichum flexicaule, Dicranum spp., Plagiothecium denticulatum, Isopterygiopsis pulchella, Pohlia cruda, Conostomum tetragonum, Distichium capllaceum, Bartramia ithyphylla; Grimmia jacutica was found once on side walls of rocks in a rock-field.

8. Grey rocks (wet and more or less exposed). Only few cliffs of grey rocks were found in the area (Fig. $3 \mathrm{H}$ ). The moss composition here includes: Brachythecium cirrosum, B. boreale, Orthothecium chryseum, O. strictum, Cyrtomnium hymenophyllum, Molendoa sendtneriana, Amphidium lapponicum, Myurella julacea, $M$. 
tenerrima, Isopterygiopsis pulchella, I. muelleriana, Timmia comata, T. austriaca, T. sibirica, Distichium capillaceum, Encalypta alpina, Plagiopus oederianus, Bartramia ithyphylla, Hypnum cupressiforme, Drepanium recurvatum.

9. Tundra-steppe slopes with Dryas punctata, Poa alpigena, P. botryoides, etc. are generally quite similar to dry variants of tundra in vascular plant composition. Here they are separated into a special item to outline the occurrence on especially dry S-facing slopes of such xerophytic moss species as Weissia brachycarpa, Tortula hoppeana, T. systilia, Syntrichia ruralis, Encalypta brevicollis, Campylopus subulatus, Bryoerythrophyllum recurvirostrum, Brachytheciastrum trachypodium.

10. Eroded soil on slopes is occupied by Polytrichum hyperboreum, Oligotrichum falcatum, Pogonatum dentatum. Small soil banks on slopes and close to rocks occasionally have Pohlia beringensis, P. andrewsii, Conostomum tetragonum.

11. Corpophilous mosses are generally not rare, as the area is used for deer pasturing. The most common of this group is Tetraplodon paradoxus that grows in wet places as well as in quite dry tundra. More rare occurrence have Splachnum luteum, S. ovatum, Tetraplodon mnioides, T. urceolatus.

\section{LIST OF SPECIES}

The nomenclature follows Ignatov, Afonina, Ignatova et al. (2006). After species name the localites (according to map in Fig. 1) and the altitudinal range are given, and then the habitats are characterized. The main set of specimens is in MHA, with extensive duplicate material in MW and SASY.

Abietinella abietina - 2, 3, 8, 12 - 1570-1750 m xeric slopes and rock outcrops, dry Dryas and lichen types of tundra, although occasionally in more wet places, on soil and among rocks, on ledges of white cliffs covered with soil.

Amphidium lapponicum - 4, 5, 7, 14 - 1488-1900 m wet rocks (both red and grey).

Andreaea obovata - 3, 6, 7, 9 - 1580-1880 m - in small brooks in tundra and on rocks of rock-field near late snow-bed. Rare: only three localities where it occurs in abundance.

A. papillosa - 6, 8, 9-1580-1880 m - rock outcrops (especially of red rocks), along temporary brooks in tundra and among rock-fields (on brown-yellow soils), in flooded depressions (apparently tempo- rary); usually quite abundant in relevant habitats.

A. rupestris - 1, 4-12 - 1560-1925 m - on both red and granitic (grey and white) rocks and occasionally on lithosoil, in dry to wet conditions. Very common in wide range of habitats, being common in permanently wet ones, e.g., along streams and around melting snow-beds.

Arctoa fulvella - 1, 5-8, 12 - 1575-1880 m - locally common on red and grey rocks, on outcrops and in niches in rock-fields.

Aulacomnium palustre - 8, 14 - 1480-1850 m - on wet soil at lake shore and along brook in tundra.

A. turgidum - 2, 5, 8, 9, 11, 12, 14 - 1480-1825 m Larix forests, dry tundra, open slopes, ledges of wet cliffs covered with soil, brook sides. One of the most common species in wet to moderately dry habitats, in various types of tundra and forest.

Bartramia ithyphylla - 2, 4, 7, 8, 13 - 1500-1880 m rock outcrops and niches of rock-fields; scattered and not abundant.

Brachytheciastrum trachypodium - 12-1540 m - one collection on rather xeric slope with scattered Larix trees.

Brachythecium boreale - 1, 5 - 1575-1800 m - wet rocks along a brook and near waterfall.

B. cirrosum - 1, 7 - 1870-1880 m - on moist cliffs near waterfall and on soil in rocky Dryas-grassy tundra.

B. udum - 7, $11-1650-1880 \mathrm{~m}$ - wet sides of brooks in tundra and near snow-beds.

Bryoerythrophyllum recurvirostrum - 2, 4, 8, 11-13 $1560-1950 \mathrm{~m}-$ on soil among rocks in rock outcrops, rock-fields, in tundra and tundra-steppes, also on small landslides near streams.

Bryum algovicum $-8-1700 \mathrm{~m}-$ on soil among red rocks, rare.

B. amblyodon - 1, 7-9, 11, 12 - 1550-1850 $\mathrm{m}$ - in various tundra communities, on S-facing xeric tundra-steppe slopes, in niches of rock outcrops, on soil or lithosoil.

B. arcticum - 7, $11-1800-1900 \mathrm{~m}-$ in rocky tundra.

B. argenteum - 2, 8, $12-1625-1720 \mathrm{~m}-$ on bare soil in Dryas tundra and between rock-fields, on ledges of white cliffs covered with soil.

B. creberrimum - 4, $12-1750-1880 \mathrm{~m}$ - in rocky tundra and on gravel creek bar.

B. cryophilum - 3, 4, 7, 10 - 1550-1800 m-in brooks, along streams and in wet places in tundra, in spring fen.

B. cyclophyllum - 7, 12-1600-1880 m - along brooks in tundra, sporadic; once collected in deep niches of rock-field.

B. lonchocaulon - $9-1580 \mathrm{~m}$ - rocky dwarf shrubgrassy tundra.

B. pseudotriquetrum - 4, 7, 10, 11 - 1600-1900 m- 
on wet soil along brooks, among big rocks, in depressions in tundra.

Callialaria curvicaule $-1-1800 \mathrm{~m}$ - wet cliffs near waterfall.

Campylium stellatum - 2, 7, 8, 10, 11, 14 - 1480$1880 \mathrm{~m}$ - along brooks and in wet types of tundra, on moist landslides along streams, on ledges of wet cliffs near waterfall and in spring mire.

Campylopus subulatus - 12 - $1700 \mathrm{~m}$ - dry SSE-facing slope, in Rhododendron redowskianum patches in rocky tundra.

Ceratodon purpureus - 1, 6-9, 11, 12 - 1550-1800 m - on soil among rocks in rock-fields, Salix shrubs, various types of tundra (sometimes in tussocks of Dryas, Carex, etc.) and apparently on old decomposed dung (at least it very commonly occurs together with Tetraplodon paradoxus).

Cinclidium arcticum - 2, 3-1700-1735 m - in wet tundra and on soil along brook.

C. stygium - 1, 10 - 1600-1800 m - on wet rocks, in boggy places among rock-fields and in spring mire.

Cnestrum alpestre - 7, $11-1600-1830 \mathrm{~m}$ - in relatively dry tundra and among rocks in rock-fields; usually in small quantity.

C. schistii - 8-1560-1570 $\mathrm{m}-$ in niche under big rock and on rock covered with lithosoil layer on rocky slope.

Conostomum tetragonum - 1, 5-9, 11-13 - 1550-1880 m - dry and rocky types of tundra, rock outcrops, niches in rock-fields, etc., not abundant, but occurring in many places.

Coscinodon hartzii - 3, 5, 7-9, 12, 13 - 1460-1880 m - common on red rock outcrops, where it is often one of two mosses with Mielichhoferia mielichhoferiana, growing on ledges and subvertical faces; more rarely grows on rocks of rock-fields and other types of rock outcrops.

Cynodontium strumiferum - 6, 8, 10-12 - 1550-1850 m - sporadic in various types of tundra, mostly its dry and rocky variants (often sheltered by bigger rocks), among rocks in rock-fields and between rocks at brook banks.

C. tenellum - 1, 8, 11-13 - 1500-1720 m - rare in tundra and sporadic in niches among rocks, as well as on rock outcrops.

Cyrtomnium hymenophyllum - 1, 7 - 1800-1880 m rare, on wet cliffs near waterfall and on soil in rather wet gravelly tundra.

Dicranella cerviculata - 9-1560 m - on bare soil in wet tundra.

D. subulata - 1, 9, 13 - 1580-1700 m - rare in gravelly tundra on soil.

Dicranum acutifolium - 2, 4, 7-12 - 1550-1880 m rather frequent but not abundant in tundra on soil and in wet niches between rocks of rock-fields, in open larch forest, once collected in spring mire.
D. angustum $-7,8-1565-1870 \mathrm{~m}-$ in rocky tundra on soil.

D. bardunovii $-8-1550 \mathrm{~m}-$ in niches between rocks on dry S-faced rocky slope.

D. elongatum - 1, 3, 6-9, 11, 12 - 1520-1800 m - very common in various types of tundra, both wet and dry, often dominates in mossy tundra and in boggy larch forests, also grows in niches between rocks of rock-fields and on wet cliffs near waterfall, on soil along brooks and in spring mire.

D. laevidens - 9, 11-13-1500-1780 m - on ledges of wet cliffs and in moss carpet in larch forest, between rocks of rock-field in tundra, in sedge-cotton grass and dwarf shrub-sedge mires.

D. leioneuron $-9-1540 \mathrm{~m}-$ on soil in boggy open larch forest.

D. majus - 8, 9, 11, 12 - 1540-1850 m - rare, in deep wet niches between rocks of rock-field, on rocky open site and in Sphagnum carpet in larch forest.

D. spadiceum var. subscabrifolium - 8, 9, $12-1700$ $1740 \mathrm{~m}$ - rare, in deep niches of rock-fields on Sfacing slope and in rocky tundra at creek terrace.

Didymodon validus - 1, 13 - 1450-1800 m - two collections: on wet cliffs near waterfall and on exposed rock outcrops at creek bank.

Distichium capillaceum - 2, 7, 8, 10, 11 -1600-1820 m - sporadic, on soil in gravelly tundra and tundrasteppe, on landslides and between rocks along brooks, on soil in dry bed of brook, in spring mire with Rheum.

Ditrichum flexicaule - 1, 7, 8, 10, 11 - 1600-1800 m - in rocky dwarf shrub-mossy and grass-lichenmossy tundra, on ledges of wet cliffs near waterfall, on landslides along brooks, in dry bed of temporary brook, on soil between rocks of rock-field, in spring mire with Rheum.

D. pallidum - 1, $11-1680-1700 \mathrm{~m}$ - in niches of rock-field, in shrub-lichen and rocky tundra on steep slope, in three places.

Drepanium recurvatum - $1-1800 \mathrm{~m}$ - on wet ledges of cliffs near waterfall.

Encalypta alpina - 1, 4 - 1800-1900 m - on wet ledges of cliffs near waterfall and between rocks in tundra under snow-bed.

E. brevicollis - 1, 7, 12 - 1700-1880 m - between rocks of rock-field, in niches of rock outcrops, on soil in patches of Rhododendron redowskianum and Betula fruticosa in gravelly tundra on slope.

E. brevipes - 7, $11-1770-1850 \mathrm{~m}-$ on soil in dry rocky tundra.

E. procera - 1, $7-1770-1880 \mathrm{~m}$ - in niches of rockfields and cliffs.

E. rhaptocarpa - 1, 7, 8, 11-13 - 1550-1880 m - very common in different types of tundra, especially in dry rocky tundra on steep S-facing slopes; grows 
also on ledges of wet cliffs near waterfall and between rocks of rock-fields.

Fissidens arcticus $-2-1695 \mathrm{~m}$ - in small amount, on ledge of white cliffs covered with soil.

Gollania turgens $-1-1800 \mathrm{~m}-$ one collection, on ledges of wet cliffs near waterfall.

Grimmia donniana - 6, 9, 12, 14 - 1490-1720 m - on red rocks in tundra, on vertical wall of grey rocks of rock-field, on rocks in shallow water on lake shore.

G. incurva - 6, 8, 9, 12-1570-1830 m-on side walls of rocks and niches of rock-field and in crevices of eroded red rock outcrop, on rocks in rocky tundra and on rocks in rapid brook, above water.

G. jacutica - 12 - $1735 \mathrm{~m}$ - one collection, in niches and on side walls of rocks in rock-field on gentle slope.

G. longirostris - 8, 11, 12, $13-1540-1900 \mathrm{~m}$ - on granitic rocks on dry slopes and on rocks of rockfields in tundra and larch forest.

G. reflexidens $-7-1900 \mathrm{~m}-$ one collection, on inclined dry wall of rock outcrop.

G. triformis - 6-1695 m-willow-lichen rocky tundra along brook.

Hygrohypnella polaris - 2- 4, 7-10, $13-1510-1880 \mathrm{~m}$ - common in brooks on soil and on rocks covered with soil, grows also in wet depression between rocks of rock-field and at bank of former stream bed.

Hylocomium splendens var. obtusifolium - 2, 3, 7, 9$11-1510-1900 \mathrm{~m}$ - abundant in wet mossy larch forests, common in mossy tundra, forming large cushions and carpets; collected also at bank of former stream bed, on covered with soil ledges of white cliffs, in niches of rock-field, in spring mire.

Hymenoloma crispulum - 4, 6, 7, 11, 12 - 1665-1950 m - on rocks and gravelly soil in rocky tundra, near permanent ice cover of streams, snow-beds, in niches between rocks of rock-fields, in crevices of red cliffs, often forms large cushions.

Hymenostylium recurvirostrum - 4-1900 m - in niches of rock outcrop.

Hypnum cupressiforme - 1, 7, 9, 11-13 - 1500-1800 m - in niches of wet cliffs in larch forest and in open places, near waterfall, between rocks of rock-field, on gravelly soil in rocky dwarf shrub-grassy tundra.

Isopterygiopsis alpicola $-9-1580 \mathrm{~m}-$ on soil between rocks in sedge-cotton grass tundra.

I. muelleriana - $11-1850 \mathrm{~m}$ - one collection on soil in dry rocky tundra with Cassiope tetragona on NEfaced slope.

I. pulchella - 4, 7, 8, 10-12 - 1540-1940 m - in deep wet niches between rocks of rock-fields, on landslides and among rocks along brooks, on bare soil and at bases of rocks in tundra.

Kiaeria blyttii - 6-8 - 1700-1900 m - on vertical and inclined walls of lumps of rock-field, on rocks along brook and in a pool in rocky willow-lichen tundra.

$K$. falcata $-6-1695 \mathrm{~m}-$ on gravelly soil in willowdwarf shrub-lichen tundra.

Leptobryum pyriforme - $9-1550 \mathrm{~m}$ - one collection in open boggy larch forest, between rocks of rockfield.

Loeskypnum badium - 10 - 1580-1600 m - sedgecotton grass spring mire with Rheum.

Lyellia aspera - 7 - 1880-1920 m - in niche of rock outcrop and between rocks in rocky dwarf shrubmossy tundra.

Meesia uliginosa - 2, 7, 8, 10 - 1600-1880 m - along brooks in tundra and in sedge-dwarf shrub spring mire, on ledges of white cliffs covered with soil.

Mielichhoferia elongata - $10-1600 \mathrm{~m}$ - one collection in niche of rock outcrop.

M. mielichhoferiana - 5, 6, 13-1460-1650 m-abundant in crevices, on ledges and overhanging surfaces of red rock outcrops and conglomerate of red rocks, pebbles and soil, more rarely on other types of rock outcrops.

Mnium blyttii - 1 -1770 m - between rocks of rockfield.

M. lycopodioides - 1, $12-1600-1880 \mathrm{~m}$ - in deep niches between rocks of rock-fields and on side walls of rocks, in niches of rock outcrops.

M. thomsonii - 1 $-1800 \mathrm{~m}-$ on ledges of wet cliffs and on rocks near waterfall.

Molendoa sendtneriana - 1-1800 m - on ledges and in crevices of wet cliffs near waterfall.

Myurella julacea - 1, 2, 8, 10 - 1550-1840 m - in niches of rock-fields, on ledges and in crevices of wet cliffs near waterfall and at brook bank, in wet tundra below snow-bed.

M. tenerrima - 1, 2, 4, $11-1695-1800 \mathrm{~m}$ - in niches of rock-fields, on ledges of white rock outcrops, in crevices of wet cliffs near waterfall and on soil between rocks in rocky dwarf shrub-lichen tundra.

Niphotrichum canescens - 7 - 1870 m - one collection, on gravelly slope below snow-bed in mountain tundra.

$N$. ericoides $-8-1800 \mathrm{~m}-$ one collection, between rocks of rock-field near stream.

N. panschii - 4, 5, 8, 10 - 1600-1880 m-common on pebble bars along streams, in depressions between rock-fields and moraine deposits, on lithosoil along brooks, in wet rocky tundra, occasionally on ledges of red rocks.

Oligotrichum falcatum - 1, 6, 8, 9, 12 - 1570-1900 m - common in niches and on ledges of rock outcrops, between rocks of rock-fields, between rocks in tundra, on rocks covered with soil, on gravelly soil along brooks, occasionally in brooks.

Oncophorus virens - 1, 2, 7, 8, 11, 12 - 1580-1920 m - in wet tundra on soil, in Betula fruticosa patches, 
on ledges of white cliffs and on rocks covered with soil, along brooks and in dry beds of temporary brooks.

O. wahlenbergii - 2, 9, $11-1660-1710 \mathrm{~m}$ - rare, in wet sedge and Dryas-mossy tundra, in sedge-cotton grass mire.

Orthothecium chryseum - 1, 2, 4, 7, 8, 10, 11 - 1580$1900 \mathrm{~m}$ - on soil and rocks in brooks and on landslides at brook banks in tundra and below snowbeds, on ledges of wet cliffs, in wet tundra and dwarf shrub-sedge mire.

O. strictum - 1 - $1800 \mathrm{~m}-$ on ledges of wet cliffs near waterfall and on soil along brook among rock-field.

Orthotrichum iwatsukii - 2, 8, 12, 13 - 1510-1800 m - on dry granitic rocks on open slopes and in larch forest.

Oxystegus tenuirostris $-1-1800 \mathrm{~m}-$ one collection, on ledges of wet cliffs near waterfall.

Philonotis fontana - 1-3, 5, 7, 8, 10, 11, 13 - 1500$1880 \mathrm{~m}$ - on soil and rocks along brooks and at bank of former stream bed, on ledges of wet cliffs (both white and red), in wet places in tundra, in dwarf shrub-sedge mire.

Philonotis cf. tomentella $-1-1800 \mathrm{~m}-$ one collection, on ledges of wet cliffs near waterfall.

Plagiomnium medium - 4, 12, 13 - 1500-1540 m - in niches of rock-fields and on ledges of wet cliffs in larch forest.

Plagiopus oederianus - 1, 4, 11 - 1800-1900 m - on ledges of wet cliffs near waterfall and between rocks in tundra.

Plagiothecium berggrenianum - $13-1500 \mathrm{~m}-$ on ledges of wet mossy cliffs in larch forest.

P. cavifolium - 1, 4-1700 $\mathrm{m}$ - in deep niches between rocks of rock-field.

P. denticulatum - 7-1880 m - in niches of rock-field near snow-bed.

P. laetum - 8, 12, $13-1540-1600 \mathrm{~m}$ - in niches between rocks of rock-fields on open dry S-facing slope and in larch forest.

Platydictya jungermannioides $-1-1800 \mathrm{~m}-$ in crevices of wet cliffs near waterfall.

Pleurozium schreberi - 9 - 1500-1550 m - sporadic in tundra and forest, although much rarer than $\mathrm{Hy}$ locomium and Rhytidium, occasionally on hummock and shrubby mires [under-represented in collections, and annotated here mostly from releve data].

Pogonatum dentatum - 3, 5, 6, 8, 9-1575-1800 m on ledges of red cliffs covered with soil, in crevices and on ledges of conglomerate of red rocks and soil along stream, on wet soil at brook banks, on soil in tundra, between rocks of rock-fields, occasionally in brooks.

P. urnigerum - 4, 6-8, $12-1690-1900 \mathrm{~m}-$ in crevices of red cliffs, on rubbly soil in rocky tundra on NE- facing slope, on lithosoil along brook and on soil and rocks in brook below snow-bed.

Pohlia andrewsii - 8, 11, 13 - 1550-1900 m - on soil at brook bank, in dry rocky tundra on $\mathrm{N}$-faced slope and on landslide in larch forest.

P. beringiensis $-7,11-1850-1880 \mathrm{~m}-$ on soil in dry rocky tundra with Dryas, Cassiope and lichens, in niches of grey cliffs.

P. cruda - 1, 2, 4, 7-9, 11-13 - 1500-1880 m - in niches of rock-fields and rock outcrops, on ledges of wet cliffs in larch forest and in open places.

P. crudoides - 5, 6, 9, 11-13 - 1575-1920 m - in niches, crevices and on ledges of red rocks, in rocky willow-dwarf shrub and other types of tundra, between rocks of rock-fields.

P. drummondii $-6-1700 \mathrm{~m}-$ on gravelly soil in tundra.

P. filum $-8-1820-1900 \mathrm{~m}-$ on clayish soil along brook in tundra on gentle slope and between rocks in Dryas-sedge tundra.

P. longicollis - 8, 12, $13-1540-1750 \mathrm{~m}-$ in niches between rocks of rock-fields and under rocks and boulders.

P. nutans - 6, 8-10, 12, $14-1490-1720 \mathrm{~m}-$ on soil in dry rocky tundra in sheltered places under rocks, dwarf shrubs and lichens, between rocks of rockfields, in crevices of red rocks and on rocks with soil layer at lake shore.

P. wahlenbergii - 8, 10, 11 - 1600-1820 m - on landslide at brook bank and in brook on soil.

Polytrichastrum alpinum - 6-8, 11-13 - 1500-1825 m - in niches of rock-fields and red cliffs, on ledges of wet cliffs in larch forest, at brook banks, between rocks in tundra.

Polytrichum hyperborium - 2, 6-9, 12 - 1550-1880 m - in niches between rocks of rock-fields, in crevices of conglomerate of red rocks and soil, on ledges of white cliffs, on gravelly slope below snow-bed, in tundra in open places and under Betula dwarf shrubs, occasionally in brooks.

P. jensenii - 6, 7, 9, 10 - 1580-1900 $\mathrm{m}$ - along brook banks in tundra and occasionally in brooks on soil and rocks, in sedge-cotton grass mire and in willow-lichen rocky tundra.

P. juniperinum $-10-1600 \mathrm{~m}-$ in dry rocky tundra.

P. piliferum - 1, 6, 8, 9, 11-13 - 1550-1850 m - on soil and on rocks with soil layer in dry rocky tundra on steep and gentle slopes, between rocks in rockfields, under Betula fruticosa patches.

P. strictum - 8, $13-1565-1600 \mathrm{~m}$ - in wet depression on SE-facing rocky slope, with Aulacomnium turgidum, and in boggy tundra, among Sphagnum centrale.

Pseudoleskeella tectorum - $13-1510 \mathrm{~m}-$ on rock in steppe community on open S-facing slope above larch forest. 
Psilopilum cavifolium - 1, 7-1770-1880 m - in rocky tundra on soil.

Pterigynandum filiforme - $12-1600 \mathrm{~m}$ - in deep niches of rock-field on gentle SSE-faced slope.

Racomitrium lanuginosum - 6, 7-9, 11, 12 - 1540$1880 \mathrm{~m}$ - between rocks of rock-fields, under rocks and boulders in tundra, on soil in tundra and in rocky bare places.

Rhizomnium andrewsianum - $10-1600 \mathrm{~m}$ - along brooks in dwarf shrub-sedge spring mire with Rheum.

Rhytidium rugosum - 1, 2, 8, 11, 12 - 1540-1800 m on soil in dry and wet tundra, on ledges of cliffs, in niches of rock-fields in tundra and larch forest.

Saelania glaucescens - 8, 11-13 - 1580-1900 m - on soil and between rocks in dry rocky dwarf shrublichen tundra, between rocks in rock-fields and at creek banks.

Sanionia uncinata - 1, 4, 5, 7-9, 11, 12 - 1540-1900 m - on soil and rocks along banks and in water of brooks, in niches between rocks of rock-fields, in dwarf shrub-mossy open larch forest, on gravelly soil in tundra, in mossy tundra with Dryas.

Schistidium boreale $-8-1795 \mathrm{~m}$ - in horizontal crevice of lump near stream.

S. frigidum - 1, 4, 9 - 1600-1950 m - on rocks of rock-fields, on rock near stream.

S. liliputanum - $13-1450 \mathrm{~m}-$ in crevice of exposed cliffs at stream bank.

S. obscurum - 7 - $1850 \mathrm{~m}-$ on rocks near permanent snow-bed.

S. papillosum - 1, 7, $11-1680-1880 \mathrm{~m}-$ on rocks and gravelly soil in wet tundra near brooks, below snowbeds.

S. platyphyllum - 2-4, 7, 8, 12, 13 - 1510-1850 m on rocks and soil in brooks in wet tundra, near snowbeds, at bank of former stream bed in flood valley.

S. pulchrum - 2, 7, $11-1695-1880 \mathrm{~m}$ - on surface of white cliff, on rocks in gravelly tundra below snowbeds and in dry rocky tundra on NE-faced slope.

S. tenuinerve - 1, 4, 7 - 1700-1800 m, in crevices of wet cliffs near waterfall and on rocks in wet tunda below snow-beds.

Scorpidium cossonii - 3 - $1750 \mathrm{~m}$ - along brook in dwarf shrub-mossy-lichen tundra.

S. revolvens - 3, 4, 9, 10, $14-1485-1940 \mathrm{~m}$ - in wet tundra, on soil at brook bank, in sedge-cotton grass mires and on wet soil at lake shore.

S. scorpioides - $14-1485 \mathrm{~m}$ - in shallow water between rocks at lake shore.

Seligeria campylopoda - 7-1910 m - in niches and semi-exposed rock faces of outcrop at mountain pass.

Sphagnum aongstroemii - 2, 9, 12 - 1550-1650 m in boggy dwarf shrub-cotton grass tundra.

S. balticum - 9, 10, $14-1490-1580 \mathrm{~m}$ - in boggy open larch forest, in dwarf shrub-sedge and dwarf shrub-cotton grass mires among rocky tundra, on boggy shore of lake.

S. centrale $-13-1600 \mathrm{~m}-$ in boggy tundra in stream valley.

S. compactum - 9-1550 m - in boggy dwarf shrubcotton grass mire on terrace of stream.

S. fimbriatum - 4, 9-11 - 1550-1700 m - in boggy open larch forest, in sedge-cotton grass mire and along brooks in wet tundra.

S. fuscum - 1, 9, 10, 13 - 1485-1700 m - on boggy shore of lake, in open boggy larch forest, in sedgecotton grass spring mire with Rheum, in wet depressions in rocky tundra and in boggy tundra in stream valley.

S. girgensohnii - 9, $13-1500-1600 \mathrm{~m}-$ in open boggy larch forest, in dwarf shrub-cotton grass mire on terrace and on ledges of wet cliffs in larch forest.

S. lenense - 9-14 - 1485-1550 m - on boggy shore of lake, in open boggy larch forest and in dwarf shrubcotton grass mire on gentle slope of terrace.

S. mirum - 9-1550 - in boggy places in tundra.

S. obtusum $-14-1490 \mathrm{~m}-$ in shallow water between rocks at lake shore.

S. rubellum - 9, 13, 14 - 1490-1600 m - in open boggy larch forest and in dwarf shrub-cotton grass mire on terrace of stream, on boggy shore of lake.

S. subfulvum - 9-1550 m - in boggy places in tundra.

S. warnstorfii - $11 \mathrm{~m}-1650 \mathrm{~m}-$ along brook in wet dwarf shrub-mossy tundra.

Splachnum luteum - 8-1550 - on decomposed dung in wet tundra.

S. ovatum - 1, 8, $10-1550-1580 \mathrm{~m}-$ in brook in boggy tundra and in wet tundra on terrace of stream.

Stereodon bambergeri - $1-1770 \mathrm{~m}-$ in niches of rock-field.

S. holmenii $-8-1550 \mathrm{~m}-$ between rocks of rockfield on S-faced slope.

S. plicatulus $-8-1550 \mathrm{~m}-$ between rocks of rockfield on S-faced slope.

S. revolutus - 1, 7, 12-1700-1880 m - on ledges of wet cliffs near waterfall, on soil along brook in wet tundra under snow-bed and under Betula fruticosa in dry dwarf shrub-lichen tundra on SSE-faced slope.

Straminergon stramineum - 14-1490 m - in shallow water between rocks at lake shore.

Syntrichia ruralis - 2, 7, 8, 11-13 - 1510-1880 m - in open places and under Rhododendron redowskianum and Betula fruticosa patches in rocky tundra on steep SSE-faced slope, on ledges of white cliffs with soil layer, on soil and rocks in rocky tundra and in niches of rock-fields on open slopes and in larch forest.

Tetraplodon mnioides - 3, 9, 11 - 1580-1880 m on soil and dung in rocky tundra on open $\mathrm{N}$-faced slope and on terrace of stream, in sedge-cotton 


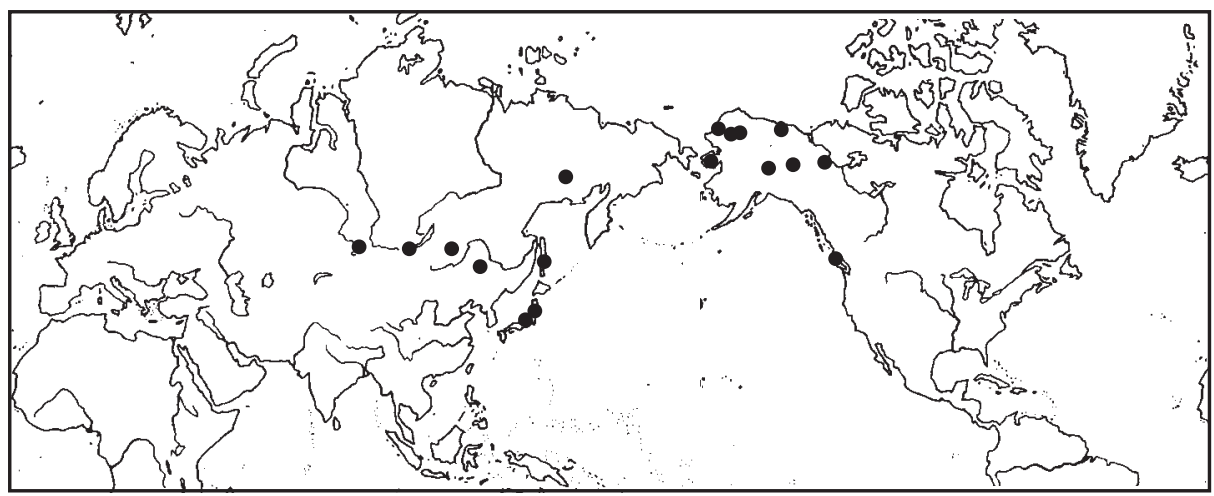

Fig. 2. World distribution of Gollania turgens (based on Higuchi (1985) list of localities, map of Steere (1978) and collections in MHA).

grass mire.

T. paradoxus - 1, 2, 9, 11-13 - 1540-1950 m - on soil and decomposed dung in different types of tundra, both dry and wet, in open boggy larch forest, in niches of rock-fields.

T. urceolatus $-8,12-1565-1735 \mathrm{~m}-$ on soil and decomposed dung in dry rocky lichen and dwarf shrub-Dryas-lichen tundra and in Pinus pumila stand.

Timmia austriaca $-1-1800 \mathrm{~m}-$ on ledges of wet cliffs near waterfall.

T. comata - 2, 11 - 1660-1695 m - on ledges of white cliffs covered with soil, in dry stream bed and in grass community in wet depression of slope.

T. sibirica - 1, $4-1700-1950 \mathrm{~m}$ - on ledges of wet cliffs near waterfall, between rocks of rock-field at cliff base.

Tomentypnum nitens - 2, 10, 11 - 1580-1710 $\mathrm{m}$ - in wet sedge tundra, open boggy larch forest, in dwarf shrub-cotton grass mire and sedge-cotton grass spring mire with Rheum.

Tortella fragilis - 7-9, 12, 13 - 1540-1870 m - on soil in dry rocky tundra, on rocks with soil layer, between rocks of rock-fields on open slopes and in larch forest, occasionally in temporary brook.

T. tortuosa - 7, 8, 12 - 1550-1880 m - on soil in rocky tundra in dry places and along brooks, in niches under rocks and boulders and between rocks of rock-fields.

Tortula hoppeana - 8, 12 - 1550-1700 m - on soil in dry rocky tundra on $\mathrm{S}$-faced slopes.

T. mucronifolia - 1, 7 - 1800-1880 m - in niches of wet cliffs near waterfall and on gravelly lithosoil in niches of rock outcrop near permanent snow-bed.

T. systylia - 8, 11, $12-1700-1850 \mathrm{~m}$ - on bare soil in dry rocky tundra, under Dryas patches in fragmented tundra among rock-fields.

Ulota curvifolia - 13-1600 m - on boulder in larch forest.
Warnstorfia exannulata - 3, 9, 10, 14 - 1490-1730 m - in wet depressions and along brooks in open boggy larch forest on gentle slope, in rocky depression with water among tundra on terrace of stream, in shallow water between rocks at lake shore.

$W$. fluitans - 10 - 1550-1600 m - in wet depression in open boggy larch forest and in brook in boggy place at base of slope.

Weissia brachycarpa - 12 - $1665 \mathrm{~m}$ - on bare soil in dry rocky tundra on gentle SSE-faced slope.

\section{INTERESTING RECORDS AND OBSERVATIONS ON SOME TAXA}

Gollania turgens. The generally Beringian distribution of this species has been revealed by Higuchi (1985), but the great distance between Japan and South Siberia and American range of the species has been filled only now (Fig. 2), in the Mus-Khaya area, where the species has been found on rather solid cliffs near a waterfall.

Mielichhoferia elongata. Comparatively with Mielichhoferia mielichhoferiana that is more widespread (although still rare) in Russia, this species is known only in one place in the country, in the NE of Irkutsk Province (Bardunov, 2000). In the Mus-Khaya area it has been collected also only once, while $M$. mielichhoferiana was found on every "red rock" outcrops that are rather numerous in the area.

According to Shaw (2000), in North America, M. mielichhoferiana is known from fewer than 15 localities, while $M$. elongata is more common, although still very rare (about 30 localities in U.S.A., excluding Alaska plus a number of sites in Alaska and arctic Canada and Greenland).

Mielichhoferia elongata differs from the $M$. 


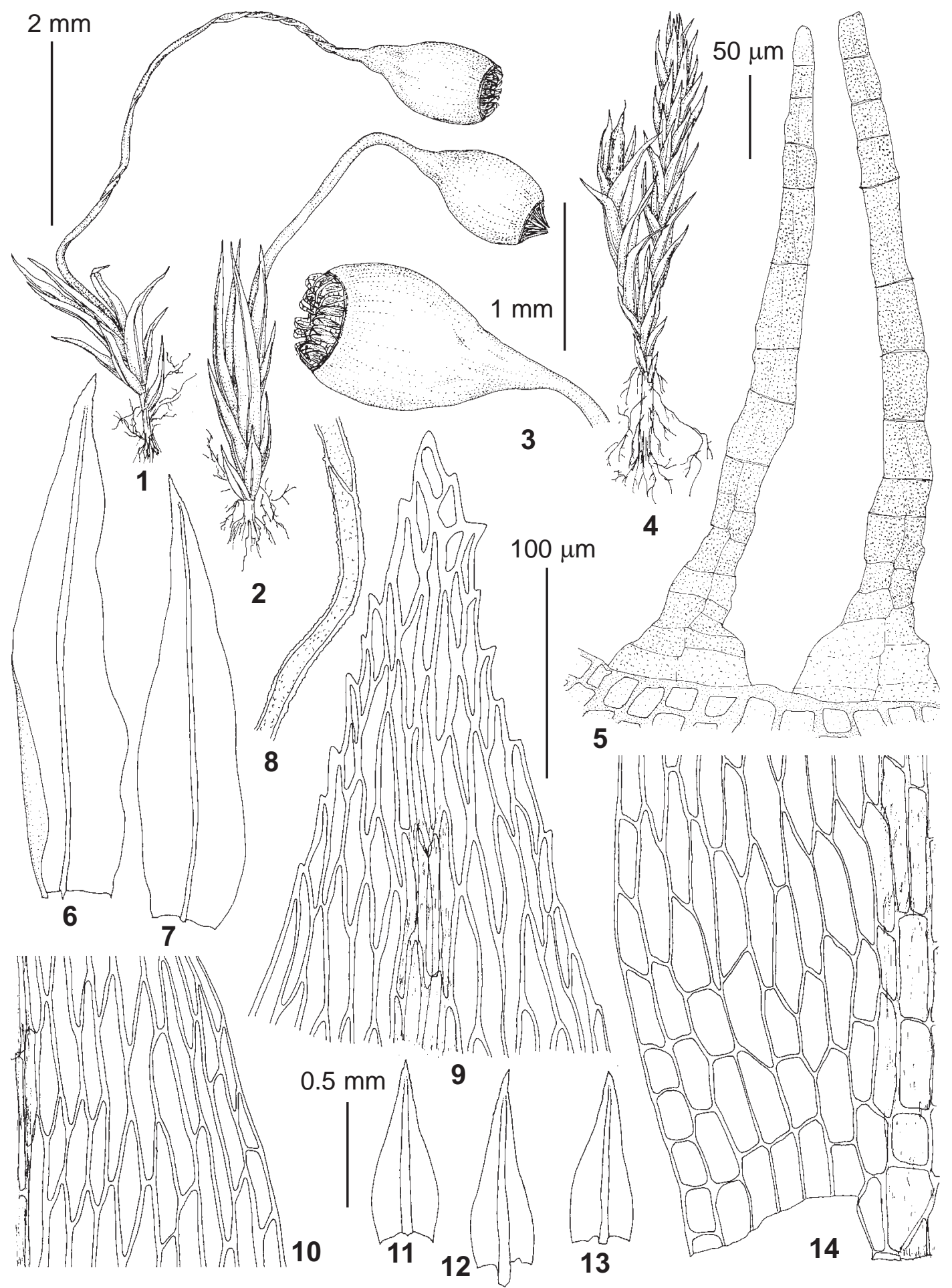

Fig. 3. Mielichhoferia mielichhoferiana (from Russia, Republic of Sakha/Yakutia, Mus-Khaya Mt., Ignatov \& Ignatova \#11-3110, MHA): 1, 4 - habit, dry; 3 -habit, wet; 3 - capsule, dry; 5 - part of peristome; 6-7 - perichaetial leaves; 8 - rhizoid; 9 - cells of apical part of leaf; 10 - median laminal cells; $11-13$ - leaves; 14 - basal laminal cells. Scale bars: $2 \mathrm{~mm}$ for 1-2, 4; $1 \mathrm{~mm}$ for 3; $0.5 \mathrm{~mm}$ for $6-7,11-13 ; 100 \mu \mathrm{m}$ for $8-10,14 ; 50 \mu \mathrm{m}$ for 5 . 


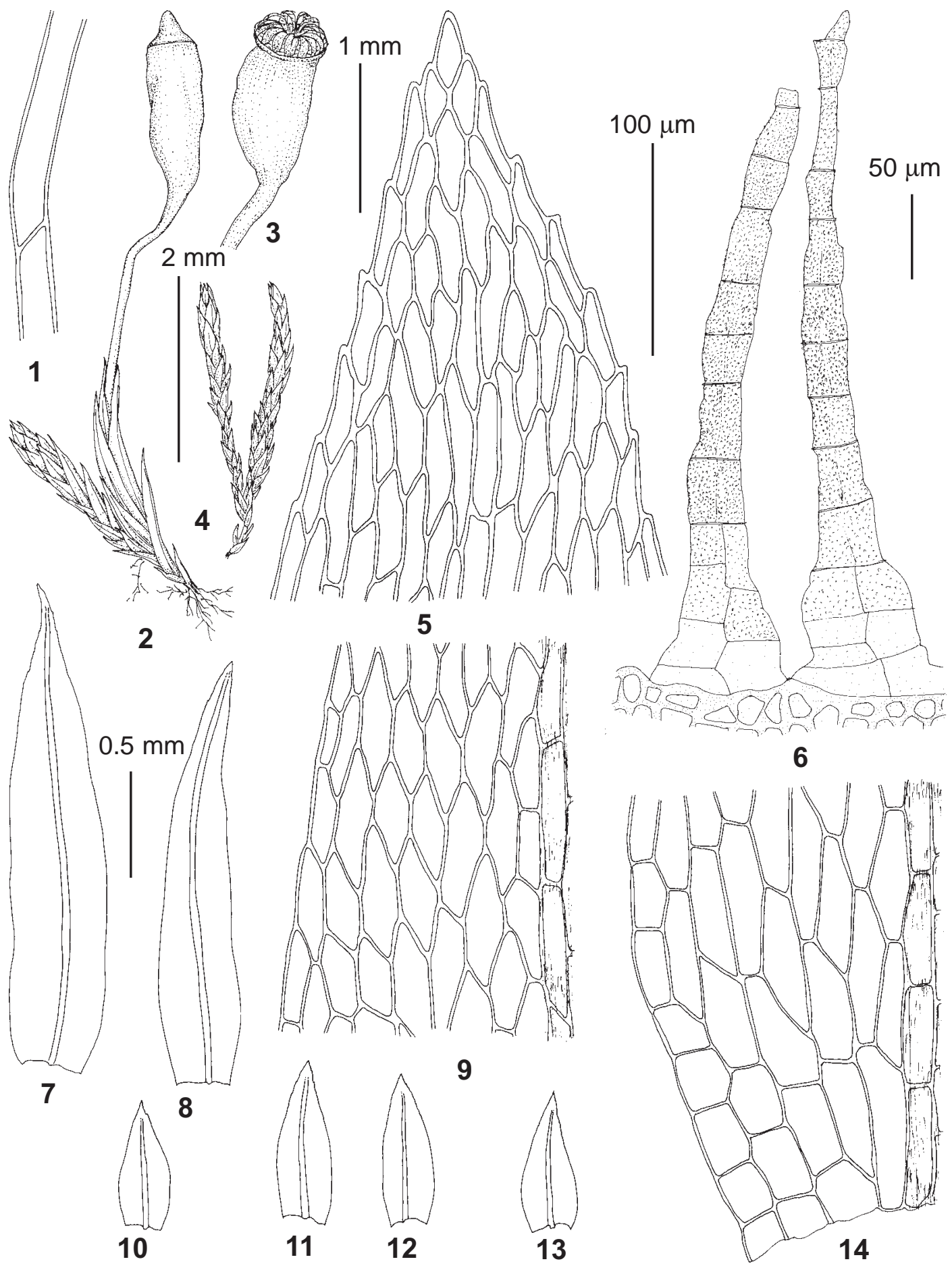

Fig. 4. Mielichhoferia elongata (from Russia, Republic of Sakha/Yakutia, Mus-Khaya Mt., Ignatov \& Ignatova \#11-3204, MHA): 1 - rhizoid; 2 -habit, wet; 3 - capsule, dry; 4 - habit, dry; 5 - cells of apical part of leaf; 6 part of peristome; 7-8 - perichaetial leaves; 9 - median laminal cells; 10-13 - leaves; 14 - basal laminal cells. Scale bars: $2 \mathrm{~mm}$ for 2,$4 ; 1 \mathrm{~mm}$ for $3 ; 0.5 \mathrm{~mm}$ for $7-8,10-13 ; 100 \mu \mathrm{m}$ for $1,5,9,14 ; 50 \mu \mathrm{m}$ for 6 . 


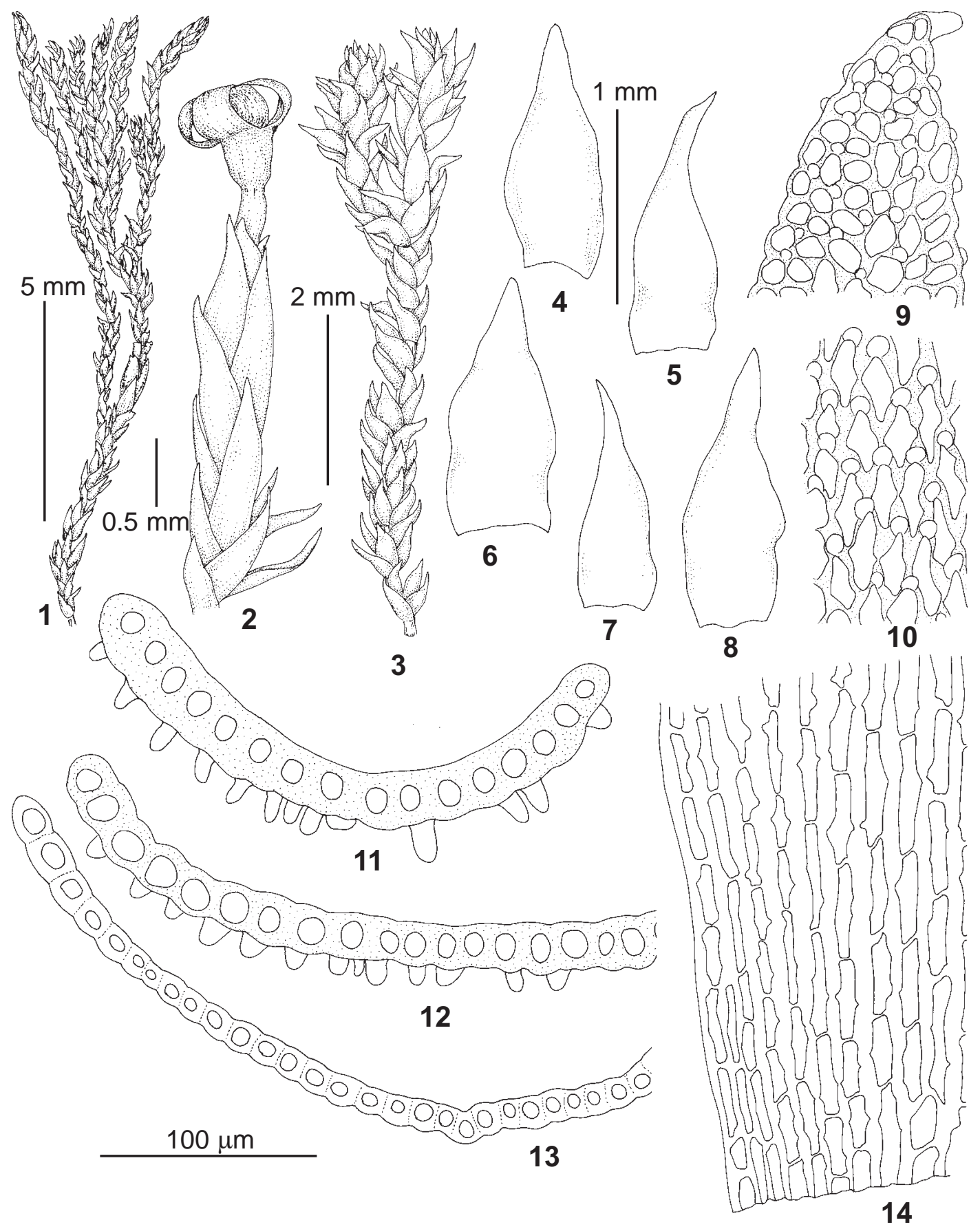

Fig. 5. Andreaea rupestris (from Russia, Republic of Sakha/Yakutia, Mus-Khaya Mt., Ivanov s.n., MHA): 1-2 - habit, dry; 3 - habit, wet; 4-8 - leaves; 9 - cells of apical part of leaf; 10 - median laminal cells; 11-13 - leaf transverse sections; 14 - basal laminal cells. Scale bars: $5 \mathrm{~mm}$ for $1 ; 2 \mathrm{~mm}$ for $3 ; 1 \mathrm{~mm}$ for 4-8; $0.5 \mathrm{~mm}$ for $2 ; 100 \mu \mathrm{m}$ for 9-14. 


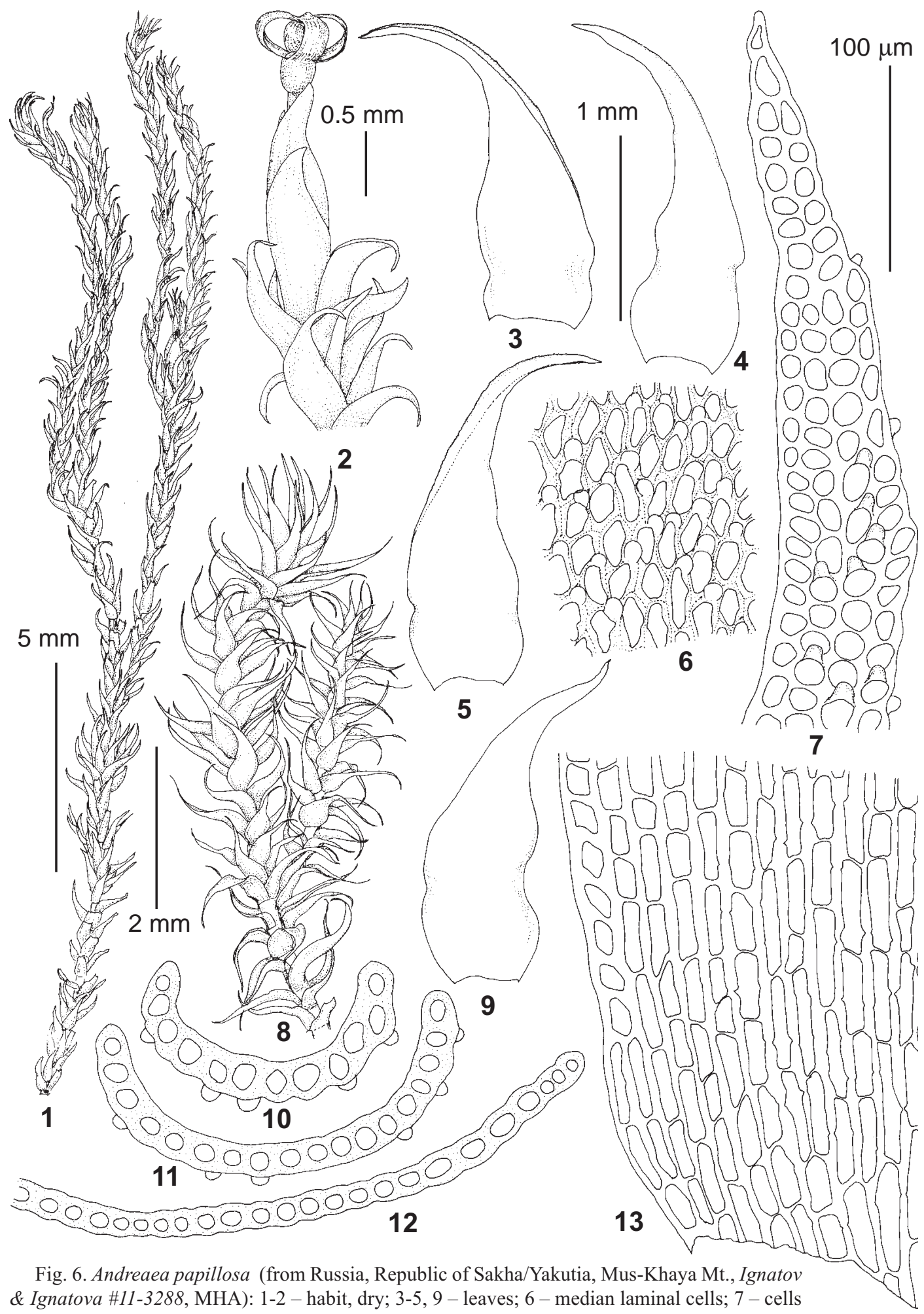
of apical part of leaf; 8 - habit, wet; 10-12 - leaf transverse sections; 13 - basal laminal cells. Scale bars: $5 \mathrm{~mm}$ for $1 ; 2 \mathrm{~mm}$ for $8 ; 1 \mathrm{~mm}$ for $3-5,9 ; 0.5 \mathrm{~mm}$ for $2 ; 100 \mu \mathrm{m}$ for $6-7,10-13$. 
mielichhoreriana in rather thin-walled laminal cells; less sharply acute leaves, and smooth or very scatteredly papillose rhizoids (cf. Figs. 3-4).

The genus Andreaea is abundant in the study area and is represented by at least three contrasting morphotypes. One grows in brooks, partly submerged, has leaves broadened above and in wet state looks julaceous; it exactly fits Andreaea obovata. It has been collected in three places, although at least in two it forms extensive populations of tens meter along a stream.

Andreaea rupestris (Fig. 5) is common in a wide range of habitats and rock types, including red ferriferous ones, where it has peculiar appearance (plants are very black, and have straight and erect-appressed narrow leaves). However broad variation of the species does not allow segregation of this form basing on morphology only.

The third morphotype (Fig. 6) is a large plant, abundantly growing both on rocks (often intermixed with A. rupestris) and on soil in temporarily flooded places, as well as upon rocks with lichens and Niphotrichum ericoides.

It was found almost always in sterile state and in a rare fertile collections no antheridia were found, so the presumably dioicous sexual condition is likely the case of this morphotype. Also, it has distinctive appearance due to patent to reflexed leaves where the acumen constitutes usually more than half of leaf length; these plants are pale ferruginaceous, somewhat similar to larger phenotypes of Didymodon ferrugineus. Stems are often longer than $10 \mathrm{~cm}$ and leaves are to $2.2 \times 0.8 \mathrm{~mm}$, comparatively with usually to $1.5 \times 0.5 \mathrm{~mm}$ in the most common expressions of $A$. rupestris in that area. These plants typically grow in a great quantity, covering sometimes many square meter, especially abundant over red rocks, although not on so exposed faces like in case of Coscinodon hartzii, and not in so sheltered crevices and overhangs like Mielichhoferia, but on moderately protected from wind and rather open parts of rock outcrops, on soil near brooks within rock-fields, etc.

These plants correspond with exsiccates from Chukotka issued by Afonina as A. rupestris var. sparsifolia, and agree with the description of $A$. rupestris var. papillosa by Murray (1988), who supported recognition of this taxon, although at infraspecific level, mostly because within its broad area there are populations with intermediate characters.

The group of Andreaea rupestris obviously requires an additional revision, but the observations like that in Mus-Khaya are much in favor of recognition of A. papillosa as a good species.

\section{ACKNOWLEDGEMENTS}

We are grateful to R.R. Sofronov, A.A. Dolzhenkov and A. Polyakov for a great help in field work, to A.V. Prokopiev for consultations on geology of the area and to A. Ivanova for correcting of the English. The work was partly supported by RFBR № 11-05-00532 and 1104-10082 and The Biodiversity Program of RAS.

\section{LITERATURE CITED}

[BARDUNOV, L.V.] БАРДУНОВ Л.В. 2000. Материалы по флоре листостебельных мхов Витимского государственного заповедника. - [Materials on flora of mosses of Vitimsky State Reserve] Иркутск [Irkutsk], 35 pp.

HIGUCHI, M. 1985. A taxonomic revision of the genus Gollania Broth. (Musci). - J. Hattori Bot. Lab. 59: 1-77.

IGNATOV, M.S., O.M. AFONINA, E.A. IGNATOVA et al. 2006 [2007]. Check-list of mosses of East Europe and North Asia. - Arctoa 15: 1-130.

[IVANOVA, E.I., E.A. IGNATOVA, M.S. IGNATOV, V.I. ZOLOTOV, K.K. KRIVOSHAPKIN] ИВAНОВА Е.И., Е.А. ИГНАТОВА, М.С. ИГНАТОВ, В.И. ЗОЛОТОВ, К.К. КРИВОШАПКИН 2005. Листостебельные мхи. - [Mosses] В кн.: Разнообразие растительного мира Якутии (ред. Н.С.Данилова) Новосибирск, Изд-во СО РАН [In: Danilova, N.S. (ed.), Raznoobrazie rastitelnogo mira Yakutii, Novosibirsk, Sib. Otd. Ross Akad. Nauk]: 105-125.

[MONTHLY METEOROLOGICAL DATA] Метеорологический ежемесячник. 1986-1988. - Якутск. Гидрометеорологический центр [Yakutsk, Gidrometeorologicheskij Tsentr] Vol. 24, pt. 2.

MURRAY, B.M. 1988. The genus Andreaea in Britain and Ireland. - J. Bryol. 15: 17-82.

SHAW, A. J. 2000. Molecular phylogeography and cryptic speciation in the mosses, Mielichhoferia elongata and M. mielichhoferiana (Bryaceae). - Molecular Ecology 9: 595-608.

STEERE, W.C. 1978. The mosses of Arctic Alaska. - Bryoph. Bibl. 14: $x+508 p p$. 